\title{
PROPOSING A TECHNICAL SOLUTION FOR RESTORING LONGITUDINAL CONNECTIVITY IN THE BRĂDENI/RETIŞ ACCUMULATION AREA ON HÂRTIBACIU RIVER
}

\author{
Răzvan VOICU *, Kelly MILES **, Robbin SOTIR ***

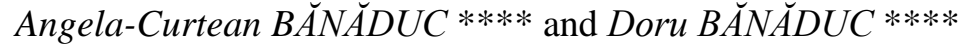

* "National Institute of Hydrology and Water Management”, București-Ploiești Street 97, București, Romania, RO-013686,rzvnvoicu@yahoo.com, getiiliberi@gmail.com

** Coquille Watershed Association, 223 N Alder, Suite D Coquille, OR-97423, US, Kelly_miles@frontier.com

*** Robbin Sotir \& Associates, Inc. 3602 Ernest W. Barrett Parkway Marietta, Georgia 30064-2732, USA, sotir@sotir.com

**** "Lucian Blaga” University of Sibiu, Applied Ecology Research Center, Dr. Ion Raţiu Street 5-7, Sibiu, Sibiu County, Romania, RO-550012, angela.banaduc@ulbsibiu.ro, ad.banaduc@yahoo.com

DOI: 10.1515/trser-2015-0080

KEYWORDS: anthropogenic wetland, Hârtibaciu River, Romania, fish conservation.

\section{ABSTRACT}

The fish fauna of the Hârtibaciu River has experienced a disrupted connectivity due to the hydrotechnical works and the Brădeni/Retiş Dam located across the Hârtibaciu watercourse being one of this significant obstacles. The newly proposed constructed wetlands can improve the habitat quality for the fish species of conservative interest sampled in the Brădeni/Retiş Dam proximity Rhodeus amarus, and can increase the individuals' number of this population. Also can benefit the local populations of Phoxinus phoxinus and Gobio obtusirostris. Using gravitational force and also the underground layout, a proposed technical solution gives maximum safety regarding the water supply for the newly proposed to be created wetlands.

RESUMÉ: Solution technique proposée pour la réhabilitation de la connectivité longitudinale du réservoir de Brădeni/Retiş sur la rivière de Hârtibaciu.

La connectivité de l'ichtyofaune de la rivière de Hârtibaciu River est interrompue en partie à cause des aménagements hydrotechniques, y compris le barrage de Brădeni/Retiş qui traverse complétement la rivière, un des obstacles les plus signifiants. Les zones humides qui viennent d'être proposées peuvent améliorer la qualité de l'habitat pour l'espèce de poisson d'intérêt conservatif échantillonnée près du barrage de Brădeni/Retiş, Rhodeus amarus, a accroitre le nombre d'individus de la population en cause. D'autres espèces peuvent en tirer bénéfice, notamment Phoxinus phoxinus et Gobio obtusirostris. Utilisant la force gravitationnelle ainsi que le contexte pétrographique, la solution technique proposée offre une sécurité maximale de l'alimentation en eau pour les zones humides à venir.

REZUMAT: Propunere de soluție tehnică pentru refacerea conectivităţii longitudinale a râului Hârtibaciu în zona lacului de acumulare Brădeni/Retiş.

Conectivitatea faunei piscicole a râului Hârtibaciu este întreruptă și datorită lucrărilor hidrotehnice, barajul Brădeni/Retiş, situat pe cursul Hârtibaciului, fiind unul dintre obstacolele cele mai importante. Zonele umede propuse a fi create pot ameliora calitatea habitatului pentru speciile de pești de interes conservativ precum Rhodeus amarus (Bloch, 1782), specie găsită în apropierea barajului Brădeni/Retiş, cu efecte favorabile la nivel populațional. De asemenea, speciile Phoxinus phoxinus și Gobio obtusirostris pot beneficia de amenajarea propusă. $\mathrm{Cu}$ ajutorul gravitației și a substratului existent în zonă, soluția tehnică propusă oferă siguranță maximă în privința furnizării de apă pentru zonele umede propuse spre înființare. 


\section{INTRODUCTION}

Connectivity fragmentation of lotic systems and the effects on aquatic diverse biota (algae, zooplankton, benthic macroinvertebrates, amphibians, fish, etc.) is a significantly increasing problem worldwide (Fuller et al., 2015; Dudgeon et al., 2005; Grill et al., 2014) and the Transylvanian hydrographical net is not an exception from this perspective (Onciu et al., 1999; Curtean-Bănăduc, 2005; Momeu et al., 2009; Bănăduc et al., 2016; Moshu et al., 2006).

According to Water Framework Directive, the ecological potential of waters is characterized by the following criteria: biological (the structure and wealth of aquatic flora, benthic invertebrate communities structure, wealth and age structure of fish fauna), hydromorphological (hydrological system, watercourse continuum, morphological conditions) and physico-chemical (salinity, acidification, thermal conditions, biogenic, oxygenation, pollution) (Water Framework Directive 2000/60/EC, 2000).

The longitudinal and lateral connectivity are severely affected by many causes, first and foremost being the hydraulic structures (dykes, dams, hydropowerplants, etc.) built along river courses. Hârtibaciu River (Cibin River basin/Olt River basin/Danube River basin) is not an exception from this non-functional wetland areas perspective. The proposed technical solution will support the lotic system restoration, in low flows conditions upstream of the Brădeni/Retiş Dam in the hot season, season with mobility and survival problems for the local ichthyofauna. The proposed constructed wetlands will circumvent the problems caused by sewage entering the river and - flood control systems of the Hârtibaciu River. Due to the proposed constructed wetlands. Each solution effectively uses the characteristics of soil and different existing hydro technical works. These wetland locations cause no impact on the hydro-technical constructions or civil structures. In fact they represent an advantage due to lower costs necessary for these types of projects. Simple yet effective design based on gravity flow water certifies the functionality of these technical solutions.

This study proposes a viable solution for improving the Hârtibaciu River continuum, in the Brădeni/RetişDam sector in accordance with Water Framework Directive2000/60/ECneeds.

\section{MATERIAL AND METHODS}

To assess the need for the proposed investment the fish communities structure was studied in the local Hârtibaciu River sector, upstream and downstream the Brădeni/Retiş Dam. The fish individuals were sampled with a mountain fishing net, in time and effort unit, identified and immediately released in their habitat.

\section{RESULTS AND DISCUSSION}

Upstream of the dam and 20 meters from the two sluices (Fig. 1), a trapezoidal earth dyke with large base of $\sim 10.5$ meters and small base of $\sim 6.5$ meters is to be built. In order to start working on the earth dyke, the Hârtibaciu River will be temporarily redirected by using a metal sheet pile wall system on the right side of the dyke (Fig. 2) in a rectangular channel with minimum five $\mathrm{m}$ depth and $1.5 \mathrm{~m}$ width. The distance between the earth dyke and the dam is $10 \mathrm{~m}$.

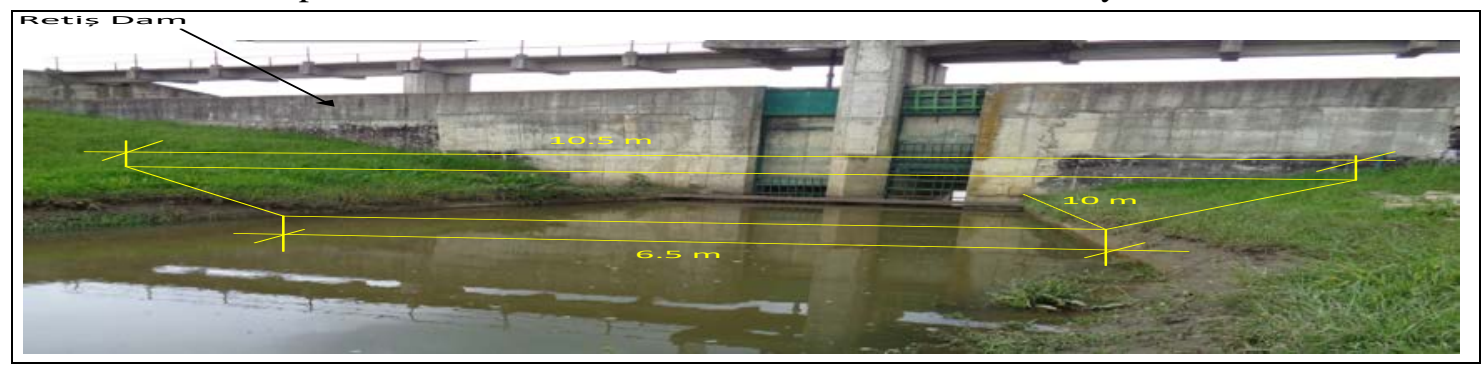

Figure 1: Positioning of the earth dyke - representative scheme. 


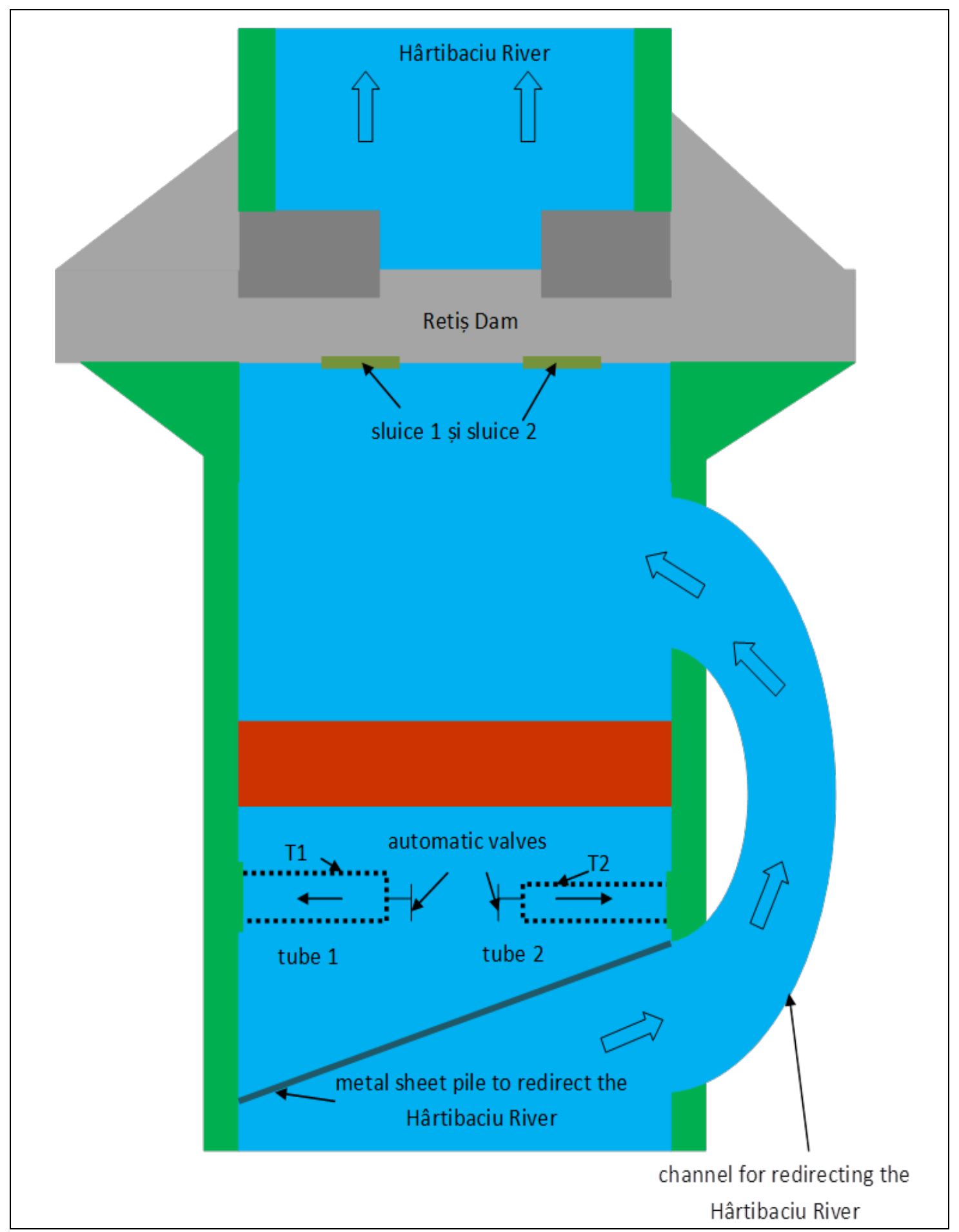

Figure 2: Locating the temporary channel to temporarily redirect the Hârtibaciu River representative scheme. 
After completing the construction of the temporary channel for redirecting the Hârtibaciu River, the earth dyke construction begins. Once the earth dyke is constructed, the two concrete tubes located underground, each equipped with automatic or manual valves (Fig. 2) are installed. The tube T2 has a smaller diameter than tube T1 (Fig. 2). After installing the concrete tubes the construction of the two basins on both sides of the Hârtibaciu River is started. Each basin has a depth of $~ 1.5$ meters and two sides (a and b, a' and b' respectively) will follow the Hârtibaciu River bed (Fig. 3).

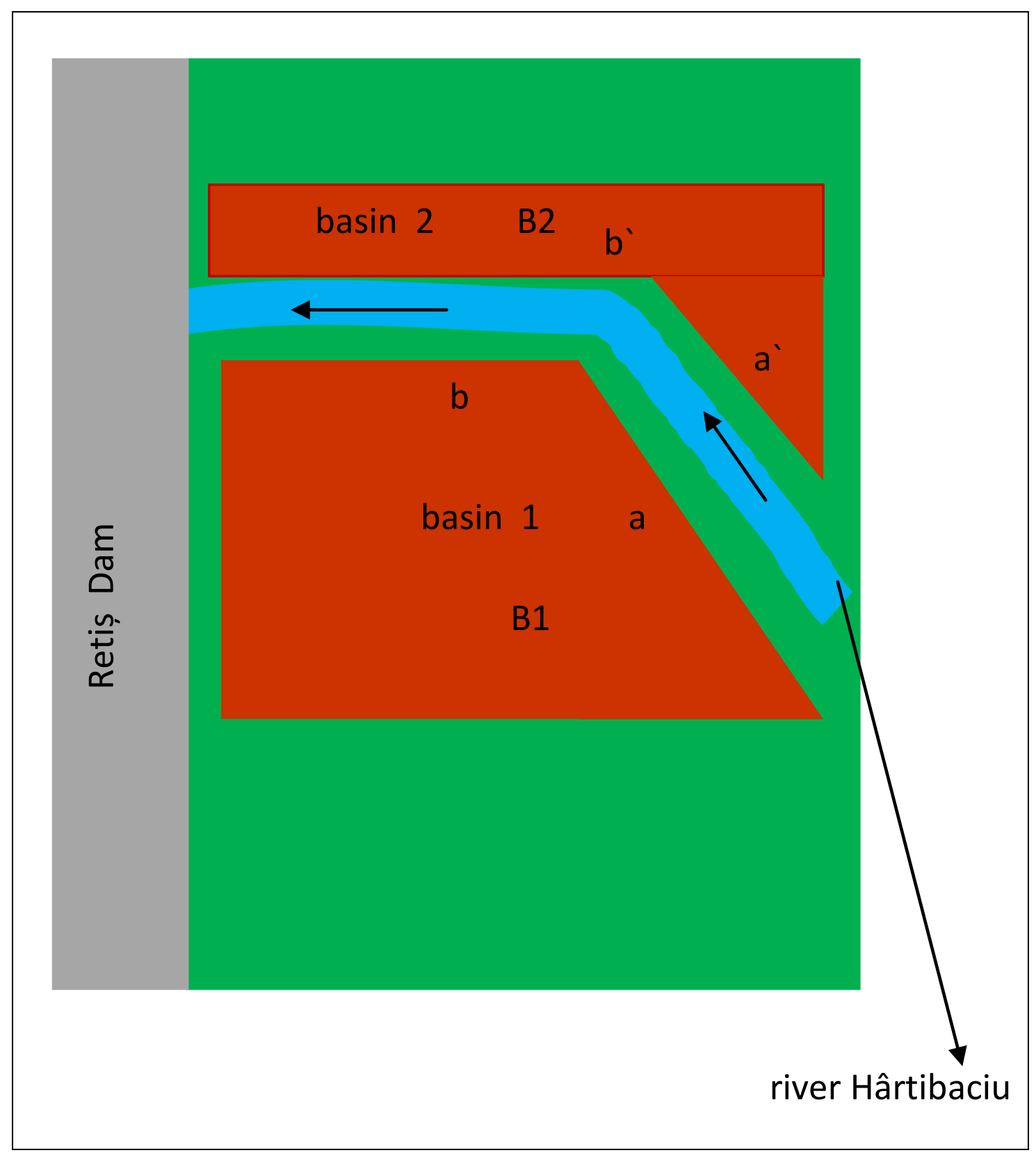

Figure 3: The location of the two basins/wetlands - representative scheme. 
The banks of the two basins/wetlands 1 and 2 will be sloped. To provide stability and connectivity to the wetland proper, it is recommended that relatively fast-growing native woody species, preferably shrubs or multi-stemmed low growing trees to be planted/installed (e.g. Alnus sp., Salix sp., etc.). Tree species are not recommended due to the possibility of wind throw.

It is not advisable to use species with tap roots. Herbaceous plants with fascicular roots (e.g. sedge, fescue, etc.) also are good choices. It is also recommendable to use moisture loving species that through evapotranspiration can eliminate water from the bank, thus further contributing to stability. On the lower half of the bank partially located in water it is recommended to plant native reed, sedge, fescue, etc., and on the upper half of the bank install native woody vegetation (Populus sp., Alnus sp., Salix sp., etc.) (Fig. 4). This type of vegetation will grow and thrive on the banks of river and wetlands 1 and 2 providing healthy habitat areas and strong riparian connections for various species of amphibians, waterfowl, birds and other aquatic organisms.

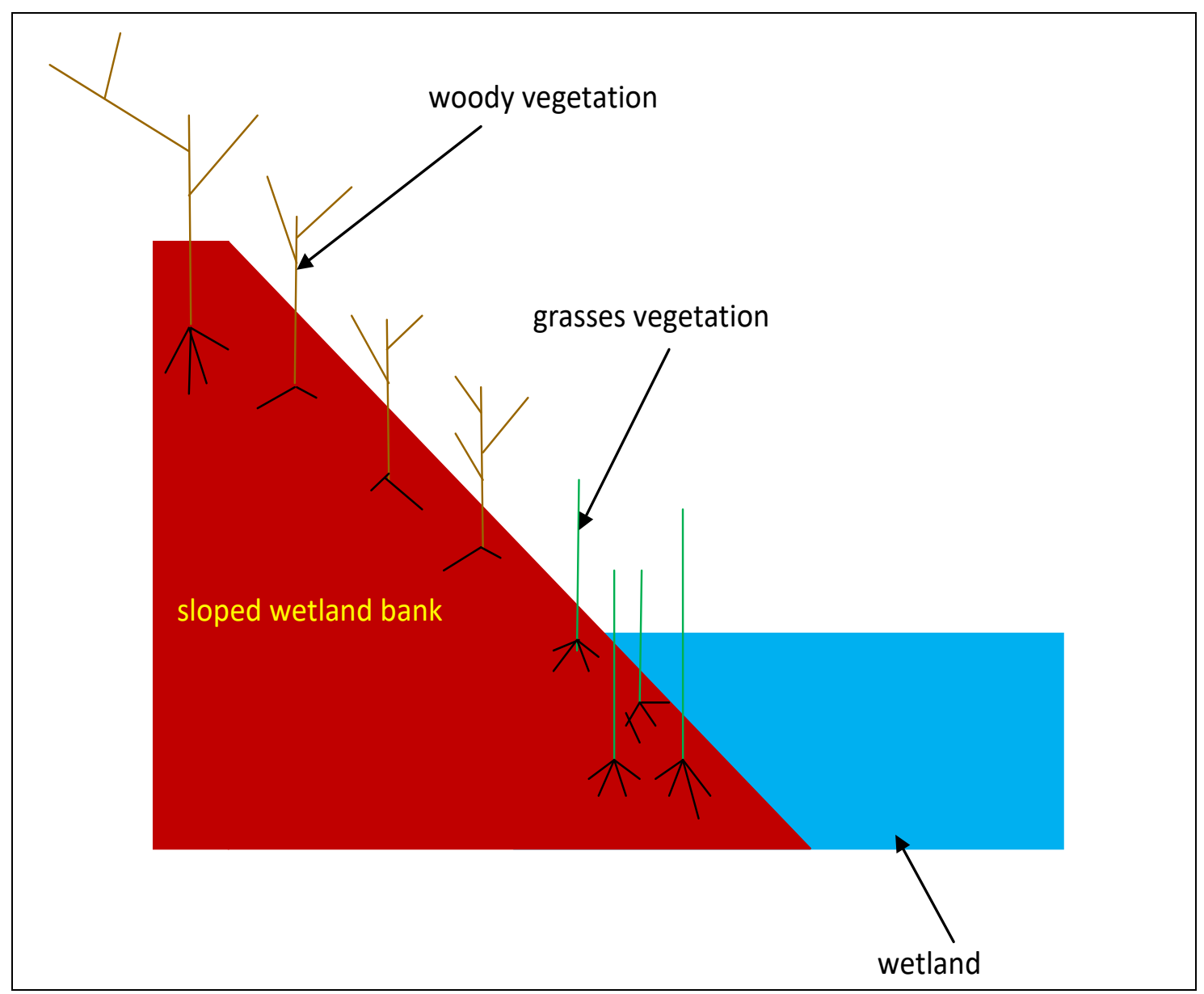

Figure 4: River bank stabilization using native woody and herbaceous vegetation - representative scheme. 
The tubes (T1 and T2) are designed to supply basins 1 and 2 with water and are calculated so that they can undertake more than the annual average flow but not the maximum flow of the Hârtibaciu River. In the case of a flood event, the two spillways inside the dam will release the excess water.

In order for the water level in the two basins to remain constant (one $\mathrm{m}$ ) and for the proper functioning of the wetland two rectangular channels C1 and C2 must be constructed in the two slopes of the dam (Fig. 5). Both channel C1 and channel C2 can accept double the amount of water in tubes 1 or tube 2. In the event of flooding both channels C1 and C2 can take a significant amount of water, thus assisting the two sills located inside Brădeni/Retiş Dam.

To prevent clogging, both tubes 1 and 2, as well as channels C1 and C2 are constructed with metal grids.

After operating the water supply system for the two basins/wetlands B1 and B2, the temporary channel for redirecting the river will be removed. The constructed wetlands will be surrounded by three $\mathrm{m}$ height metal fences to prevent people and animals from entering these areas (Fig. 6). As an additional environmental enhancement for amphibians and small animals, etc. openings (approximately $10 \mathrm{~cm}$ high and one $\mathrm{m}$ long) will be installed along the bottom of these fences, connecting the wetlands to the forest.

Soil bioengineering methods such as live fascines, brush layers and brush mattress offers a strong initial foundation and as such, are recommended for the stabilization and revegetation of the newly constructed wetland banks. These methods will provide immediate surface stability, long term soil reinforcement, water removal capabilities and over time a diverse, well connected and healthy riparian habitat.

The proposed system regarding the water supply for wetlands B1 and B2 does not affect the flow of the Hârtibaciu River nor Brădeni/Retiş Dam structure (Fig. 6).

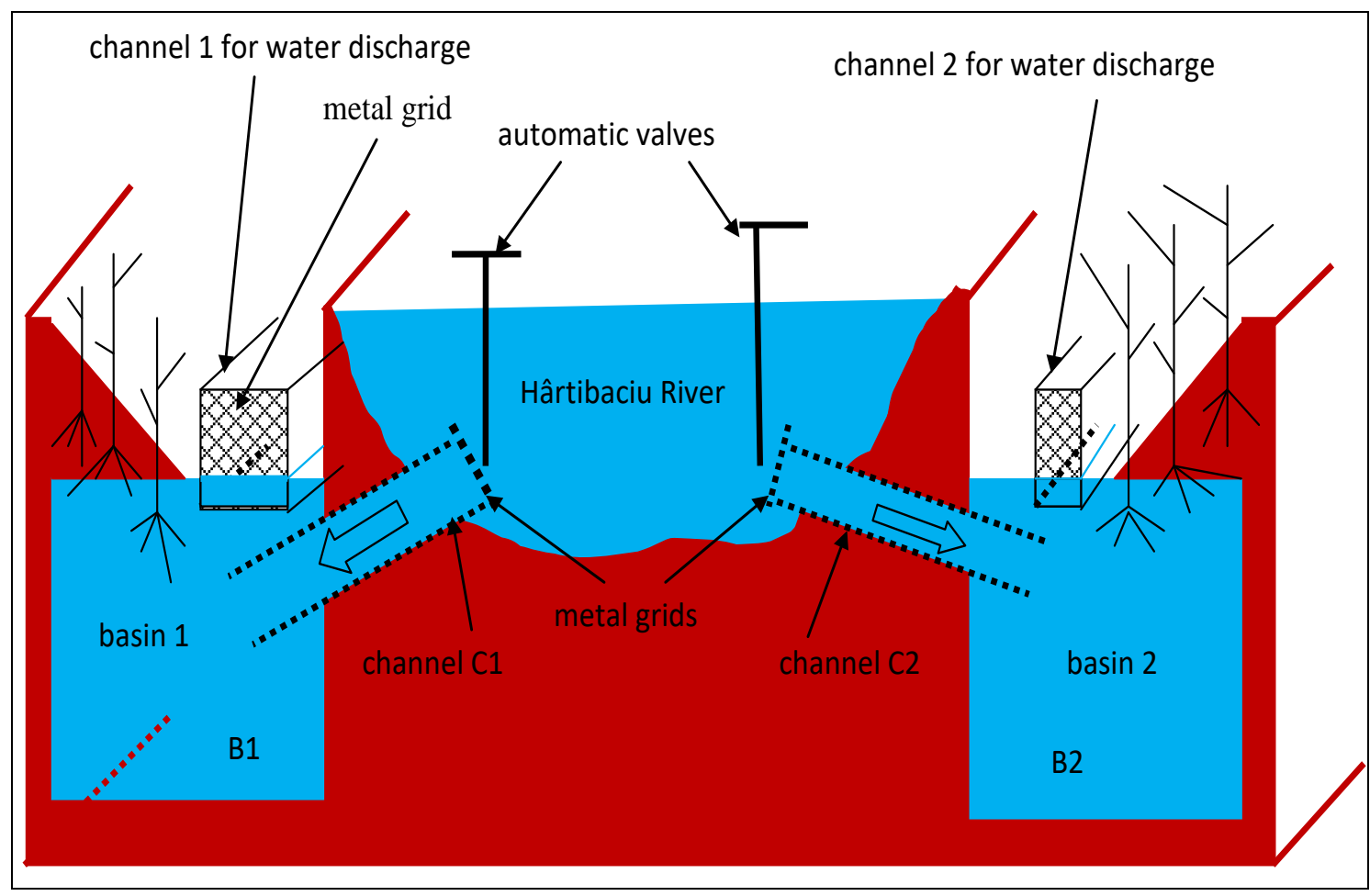

Figure 5: Positioning channels C1 and C2 - representative scheme. 


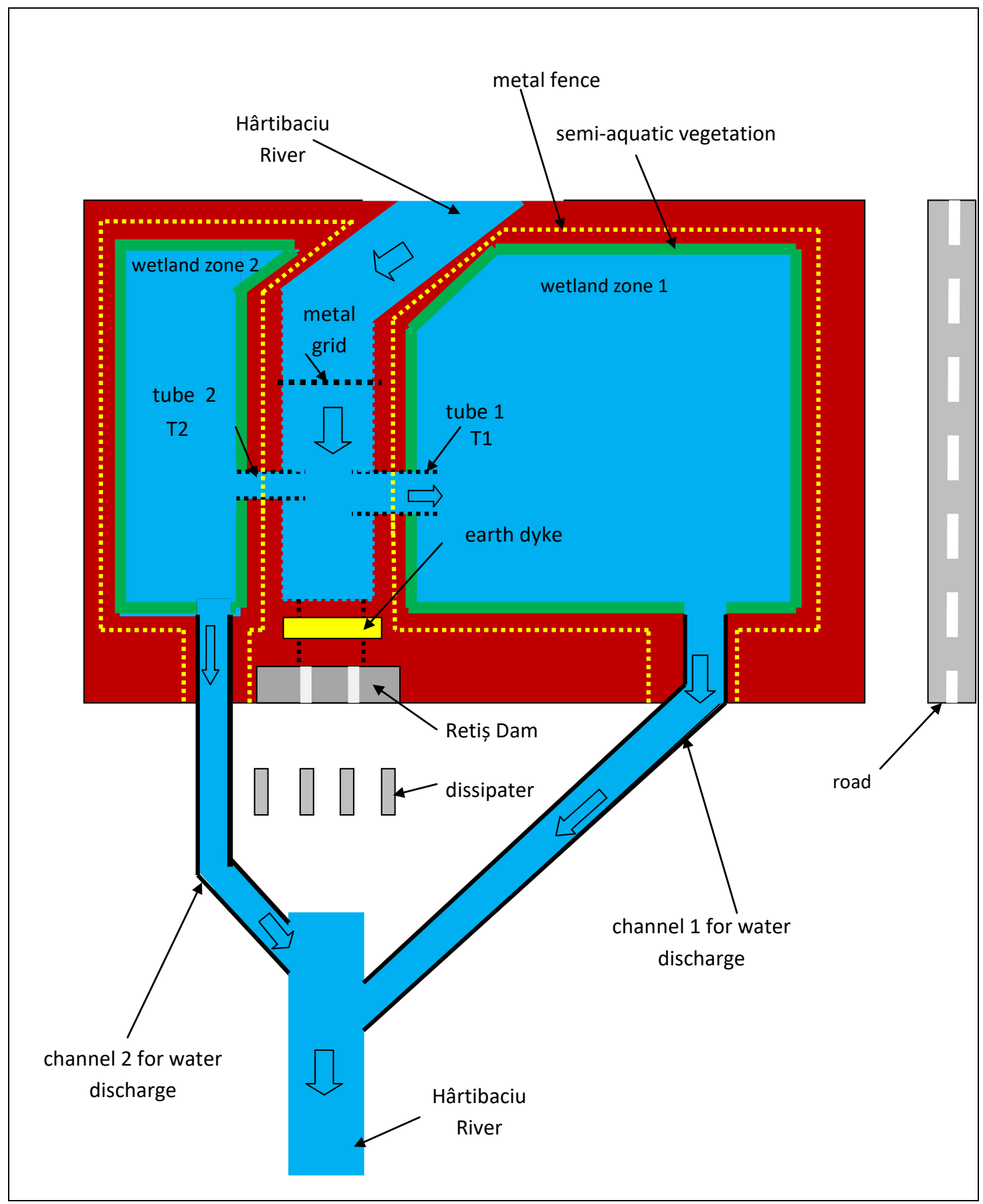

Figure 6: Wetlands and proposed system for their water supply - general representative scheme.

Using gravity to fill the two basins B1 and B2 and also the underground layout of the two tubes (channels) T1 and T2, respectively gives maximum safety regarding the water supply for the newly proposed constructed wetlands. 


\section{Advantages for the local ichthyofauna conservation.}

The Hârtibaciu River fish fauna includes a relatively high number of fish species, such as the followings: Squalius cephalus (Linnaeus, 1758), Alburnus alburnus (Linnaeus, 1758), Alburnoides bipunctatus (Bloch, 1782), Rhodeus amarus (Bloch, 1782), Gobio obtusirostris Valencienes, 1842, Romanogobio kessleri (Dybowski, 1862), Barbus meridionalis Risso, 1827, Barbatula barbatula (Linnaeus, 1758), Misgurnus fossilis (Linnaeus, 1758), Cobitis taenia Linnaeus, 1758, Sabanejewia romanica (Băcescu, 1943), and Sabanejewia aurata (De Filippi, 1863) (Bănărescu, 1964).

In the period of this study Phoxinus phoxinus (Linnaeus, 1758) was the first time recorded in the Hârtibaciu River watershed (Fig. 7).

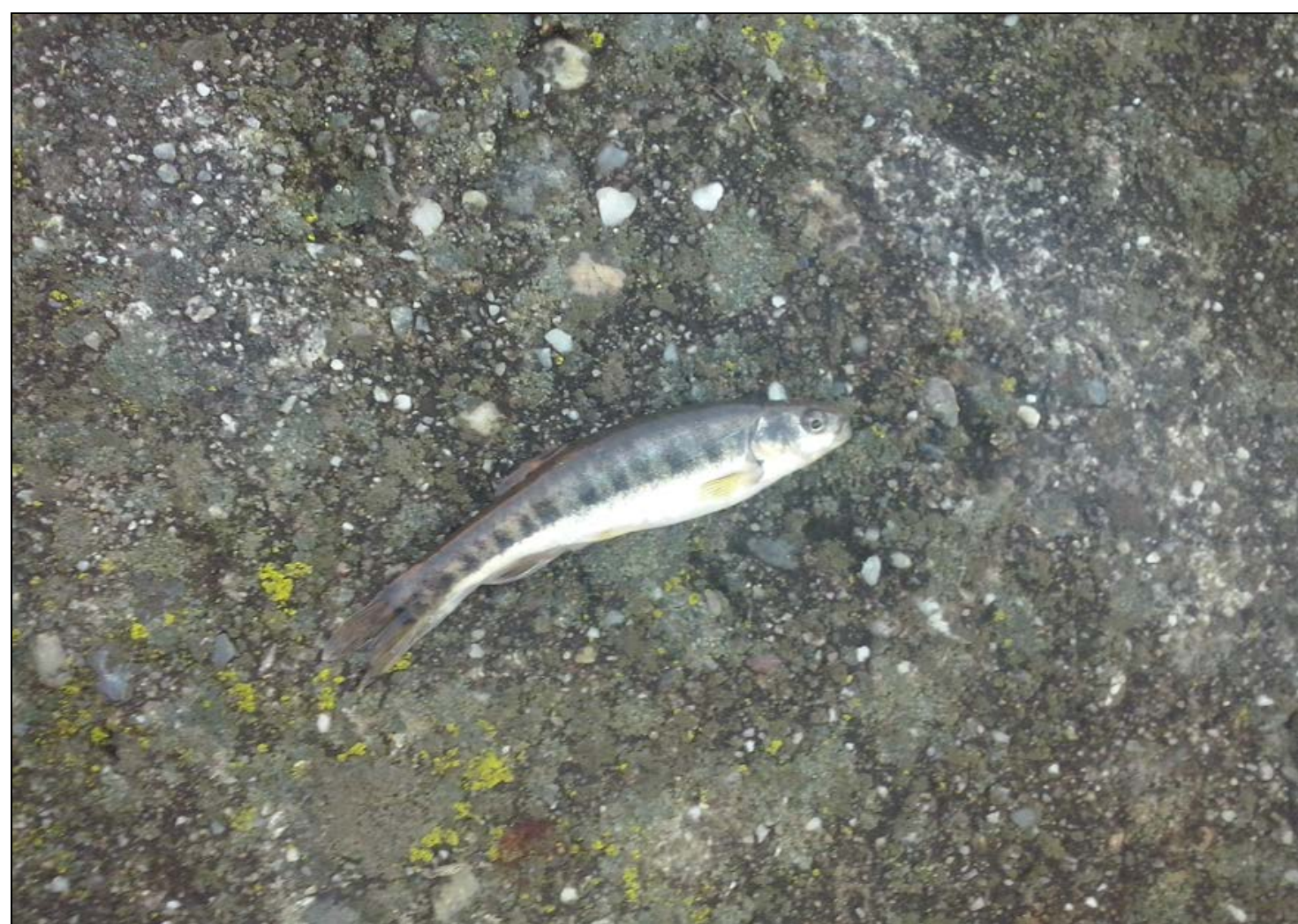

Figure 7: Sampled individual of Phoxinus phoxinus.

In the sector of 25 m downstream of the Brădeni/Retiş Dam on the Hârtibaciu River only three fish species were recorded: Phoxinus phoxinus with a relative abundance of $79.17 \%$, Rhodeus amarus with $12.5 \%$, and Gobio obtusirostris with $8.33 \%$.

In the sector of 25 m upstream of the Brădeni/Retiş Dam only Phoxinus phoxinus was found. The information gathered reveals the barrage and devastating role this dam has on the ichthyofauna, less for Phoxinus phoxinus and more accentuated for the other two fish species.

The newly proposed constructed system foundation and enhanced habitat that will be created by nature over time, should also be favourable and can be colonised by the bivalve species Anodonta cygnea (Linnaeus, 1758), which is present in Hârtibaciu River (Curtean et al., 1999; Sîrbu et al., 1999), a species which can have a positive affect for the Rhodeus amarus species reproduction (Bănărescu and Bănăduc, 2007) and for the water self-cleaning processes. 
Phoxinus phoxinus fish species is usually present in Romania in the trout and grayling and Mediterranean barbell ichthyological zones, here being in an unusual association with Rhodeus amarus characteristic species for the much lower barbell zone and Gobio obtusirostris Valencienes, 1842 characteristic for the chub zone. The dam, the banks and the human impacted riverine vegetation explains this unnatural fish occurrence.

It is also important to note that Rhodeus amarus (Fig. 8) is a protected species under the Habitats Directive (92/43/EEC). The new proposed constructed wetland can increase its abundance in the area as it provides this species with a habitat characterised by stagnant or semi-stagnant water with soft bottom (Bănărescu and Bănăduc, 2007).

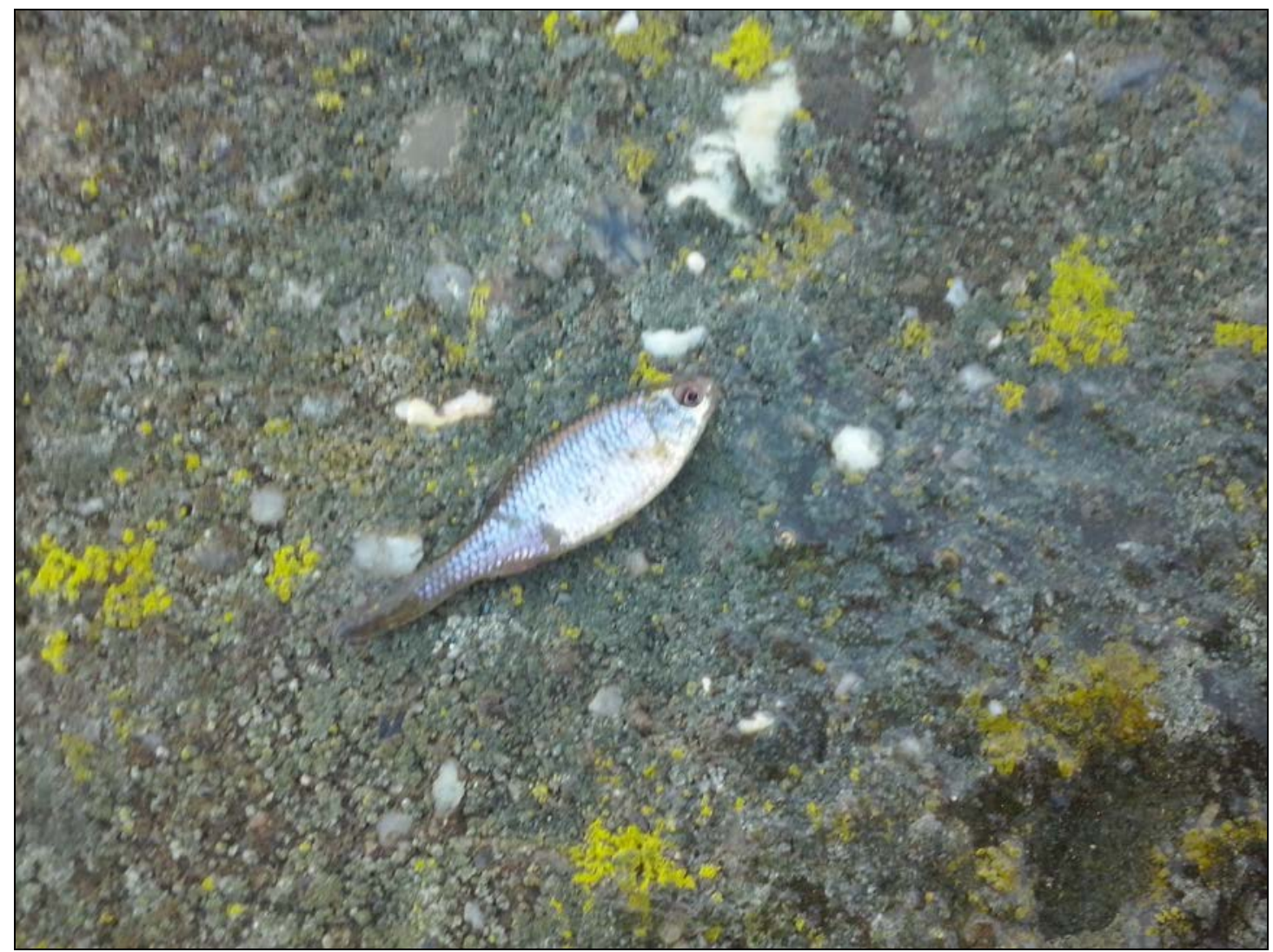

Figure 8: Sampled individual of Rhodeus amarus.

The two new proposed constructed wetlands can constitute a buffer zone for fish especially in the dry and could (with long frozen periods) seasons, and also an easy crossing passage. Aquatic and semi-aquatic birds, amphibians, molusks and aquatic and semi-aquatic vegetation can benefit also by this wetland in the future. It will continue to evolve becoming stronger and naturally more diverse, healthy and self-supporting over time. 


\section{CONCLUSIONS}

Using gravity and also the underground layout of the two tubes (channels), the proposed technical solution gives maximum safety regarding the water supply for the newly proposed constructed wetlands.

All the local fish species presently experience major disrupted movement due to the Brădeni/Retiş Dam located across the Hârtibaciu watercourse. The newly proposed constructed wetlands sets in place the foundation for the rehabilitation of the connectivity and the enhanced habitat quality for the single fish species of conservative interest sampled in the Brădeni/Retiş Dam proximity Rhodeus amarus, and increases the number of individuals of this population. Also the local fish population of Phoxinus phoxinus and Gobio obtusirostris will most certainly benefit from this renewed and increased connectivity. 


\section{ACKNOWLEDGEMENTS}

The authors thank the reviewers for their input. 


\section{REFERENCES}

1. Bănăduc D., Pânzar C., Bogorin P., Hoza O. and Curtean-Bănăduc A., 2016 - Human impact on Târnava Mare River and its effects on aquatic biodiversity, Acta Oecologica Carpatica, IX, 189198.

2. Bănărescu P. M. and Bănăduc D., 2007 - Habitats Directive (92/43/EEC) fish species (Osteichthyes) on the Romanian territory, Acta Ichtiologica Romanica, II, 43-78.

3. Curtean-Bănăduc A., 2005 - Study regarding Târnava Mare and Târnava Mică rivers (Transylvania, Romania) Stonefly (Insecta, Plecoptera) larvae communities, Transylvanian Review of Systematical and Ecological Research, 2, 75-84.

4. Curtean A., Sîrbu I., Drăgulescu C. and Bănăduc D., 1999 - Impactul antropic asupra biodiversităţii zonelor umede din bazinul superior şi mijlociu al Oltului, Edit. Universităţii “Lucian Blaga” din Sibiu, ISBN 973-651-003-4, 103. (in Romanian)

5. Dudgeon D., Arthington A. H., Gessner M. O., Kawabata Z., Knowler D. J., Lévégue C., Naiman R. J., Prieur-Richard A. H., Soto D., Stiassny M. L. and Sullivan C. A., 2006 Freshwater biodiversity: importance, threats, status and conservation challenges, Biological Reviews of the Cambridge Philosophical Society Journal, 81, 2, 163-182.

6. Fuller M. R., Doyle M. W. and Strayer D. L., 2015 - Causes and consequences of habitat fragmentation in river networks, Annals of the New York Academy of Sciences, October 1355:3151, DOI: 10.111/nyas.12853.

7. Grill G., Ouellet D., Fluet-Chouinard E., Sindorf N. and Lehner B., 2014 - Development of new indicators to evaluate river fragmentation and flow regulation at large scales: a case study for the Mekong River basin, Ecological Indicators, 45, 148-159, DOI: 10.1016/j.ecolind.2014.03.026

8. Momeu L., Battes K., Battes K., Stoica I., Avram A., Cîmpean M., Pricope F. and Ureche D., 2009 - Algae, macroinvertebrate and fish communities from the Arieș River catchment area (Transylvania, Romania), Transylvanian Review of Systematical and Ecological Research, 7, 149-180.

9. Moshu A. J., Davideanu G. and Cebanu S., 2006 - Materials on the ichthyofauna diversity of Prut River basin, Acta Ichtiologica Romanica, I, 171-184.

10. Onciu T. M., Radu A. and Galațchi L., 1999 - Contributions to the knowledge of the zooplankton from the Olt River, Transylvanian Review of Systematical and Ecological Research, 1, 67-76.

11. Sîrbu I., Sárkány-Kiss A., Petrescu M., Lazăr B. and Buian G., 1999 - Contributions to the knowledge of the freshwater mollusk fauna from the upper and middle basin of the Olt River (Romania), Transylvanian Review of Systematical and Ecological Research, 1, Edit. Universităţii “Lucian Blaga” din Sibiu, ISSN 1841-7051, ISBN 973-9410-69-3, 111-122.

12. Water Framework Directive 2000/60/EC, 2000. 